\title{
Correlation Between PSA Density and Gleason Score In Prostate Cancer Patients
}

\author{
Md. Naved Yusuf ${ }^{1}$, Sudip Das Gupta ${ }^{2}$, Mohammed Mianur Rahman ${ }^{3}$, Md. Mahmud-Ur-Rahman ${ }^{4}$
}

Received: 19 - 07 - 2020

Accepted: 17 - 09 - 2020

Conflicts of interest: None

Keywords: PSA, PSA density, Gleason Score, TRUS, Prostate biopsy

\begin{abstract}
Background: Prostate cancer is the most common form of malignancy and the second leading cause of cancer death among men. The histological grade is an independent determinant of disease prognosis and survival. The Gleason System (GS) grading is the most widely accepted classification. Several recent studies have searched for factors that could predict GS upgrading. High prostate specific antigen density (PSAD) has been shown to be predictors of risk progression in many studies, reflecting the possibility of undetected aggressive cancer.

Objective: To detect the association between PSA density and Gleason score in prostate cancer patients.

Methodology: This cross sectional study was carried out at the department of urology, Sir Salimullah Medical College Mitford hospital, Dhaka. Patients diagnosed as prostate cancer meeting the inclusion criteria admitted in the above mentioned place was the study population. Statistical analyses were carried out by using the Statistical Package for Social Sciences version 23.0 for Windows (SPSS Inc., Chicago, Illinois, USA). Student t-test was used for continuous variables. Pearson's correlation coefficient was used to test the relationship between the groups. P values $<0.05$ was considered as statistically significant.
\end{abstract}

Results: Total eighty three patients were included in this study. The mean age was found $69.2 \pm 7.7$ years ranging from 50 to 85 years. The mean volume of prostate was $42.3 \pm 17.6 \mathrm{ml}$ ranging from 13.0 to $68.0 \mathrm{ml}$. The mean Gleason score was $7.8 \pm 1.4$ ranging from 6.0 to 10.0. More than one third (33.7\%) patients had PSA density 0.15$0.5 \mathrm{ng} / \mathrm{ml} / \mathrm{ml}$. Three patients had found Gleason score $9(5+4)$ within PSA density 0.51-1.0 ng/ml/ml, 5 patients within PSA density 1.1-1.5 $\mathrm{ng} / \mathrm{ml} / \mathrm{ml}, 3$ patients within PSA density 1.51-2.0 ng/ml/ml, 6 patients within PSA density 2.1-2.5 ng/ml/ml, 5 patients within PSA density 2.51-3.0 $\mathrm{ng} / \mathrm{ml} / \mathrm{ml}$ and 2 patients within PSA density $>3.0 \mathrm{ng} / \mathrm{ml} / \mathrm{ml}$. The difference was statistically significant $(p<0.05)$ among seven groups. Positive correlation $(r=0.717 ; p=0.001)$ between PSA density with Gleason score.

Conclusion: In this study, we find there is a strong correlation between PSA density and Gleason score.

1. Medical Officer, Department of Urology, Sir Salimullah Medical College Mitford Hospital, Dhaka

2. Associate Professor \& Head, Department of Urology, Sir Salimullah Medical College Mitford Hospital, Dhaka

3. Associate Professor \& Head, Department of Urology, Potuakhali Medical College \& Hospital

4. Registrar, Department of Urology, Sir Salimullah Medical College Mitford Hospital, Dhaka

Correspondences: Dr. Md. Naved Yusuf, Medical Officer, Department of Urology, Sir Salimullah Medical College Mitford Hospital, Dhaka, Bangladesh, E-mail: naved1994@gmail.com

Bangladesh J. Urol. 2020; 23(2): 164-168 


\section{Introduction}

Prostate cancer is the second leading cause of cancer related death in men. It is also the fourth most common male malignant neoplasm worldwide. The probability of developing carcinoma prostate in a man under the age of $<39$ is 1 in 10,000 for men $40-59$ it is 1 in 103 and for men $60-79$ it is 1 in 8 . Its incidence varies between countries and ethnic populations ${ }^{1}$.

The ability to diagnose carcinoma of prostate has been enhanced by the discovery of prostate specific antigen (PSA) as a screening tumor marker. Serum PSA combined with digital rectal examination (DRE) can be used as a diagnostic tool, carcinoma of prostate can be diagnosed at an earlier stage on an annual basis ${ }^{2}$. The reference standard for the diagnosis of prostate.

The ratio of PSA to gland volume is termed the PSA density. Some investigators advocate prostate biopsy only if the PSA density exceeds 0.1 to $0.15 \mathrm{ng} / \mathrm{ml}$ / $\mathrm{ml}^{4,5}$. Some have advocated that PSA density can be calculated with transition zone volume instead of total prostate volume.

The Gleason system is the most commonly employed grading system. The system relies on the low power appearance of the glandular architecture under the microscope. In assigning a grade to a given tumor, pathologists assign a primary grade to the pattern of cancer that is the most commonly observed and a secondary grade to the second most commonly observed pattern in the specimen. Grade range from grade 1 to grade $5^{6}$. The Gleason score or Gleason sum is obtained by adding the primary and secondary grades together.

The concept of PSAD is based on the fact that in BPH the level of serum PSA is elevated due to gland tissue hyperplasia. With prostate cancer, the serum PSA elevation results from disruption of vascular architecture without a significant increase in the prostate volume. The cut off value used for PSAD is $0.15 \mathrm{ng} / \mathrm{ml} / \mathrm{ml}$. Levels above 0.15 are indicative of a malignant process, while levels below it of a benign process ${ }^{7}$.

\section{Objective}

The aim of this study was to detect the association between PSA density and Gleason score in prostate cancer patients.

\section{Materials and methods}

We conducted a cross sectional study at the Department of urology, Sir Salimullah Medical College
Mitford hospital, Dhaka. We include 83 patients who were diagnosed as prostate cancer admitted in the above mention place from January 2018 to June 2019 Exclusion criteria were Patients taking 5 alphareductase inhibitors., Patients receiving radiotherapy or chemotherapy. Patients with psychological problem.

At first the thorough history was taken from the patient. Then DRE was performed after proper counseling and consent. Then the case was selected. Data was collected after estimating S.PSA and measuring the prostate volume with the help of TRUS. PSA density was measured after dividing S.PSA by volume of the gland. Then Gleason score was collected from histopathology report after prostate biopsy.

Statistical analyses were carried out by using the Statistical Package for Social Sciences version 23.0 for Windows (SPSS Inc., Chicago, Illinois, USA). The mean values were calculated for continuous variables. The quantitative observations were indicated by frequencies and percentages. Student t-test was used for continuous variables. Pearson's correlation coefficient was used to test the relationship between the groups. P values $<0.05$ was considered as statistically significant.

All the collected data was checked \& verified for its constancy. The data was compiled, analyzed \& then tabulated according to key variables.

\section{Results}

A total of 83 patients who were diagnosed as prostate cancer meeting the inclusion criteria and admitted in the department of urology, Sir Salimullah Medical College Mitford hospital, Dhaka during the period of January 2018 to June 2019 included in this study.

The mean age was found $69.2 \pm 7.7$ years with range from 50 to 85 years. $37(44.6 \%$ ) patients belonged to age 61-70 years (Table 1 ).

Table-I: Distribution of the study patients by age $(\mathrm{n}=83)$

\begin{tabular}{lcc}
\hline Age (years) & Number of patients & Percentage \\
\hline$\leq 60$ & 11 & 13.3 \\
$61-70$ & 37 & 44.6 \\
$71-80$ & 32 & 38.6 \\
$>80$ & 3 & 3.6 \\
Mean \pm SD & 69.2 & \pm 7.7 \\
Range (min-max) & 50 & -85 \\
\hline
\end{tabular}


The mean S.PSA was found $44.7 \pm 29.5 \mathrm{ng} / \mathrm{ml}$ ranging from 4.7 to $100.0 \mathrm{ng} / \mathrm{ml}$. The majority $(28.9 \%)$ patients had S.PSA d" $20 \mathrm{ng} / \mathrm{ml}$ (Table II).

Table II : Distribution of the study patients according to S.PSA $(n=83)$

\begin{tabular}{lcc}
\hline S.PSA $(\mathrm{ng} / \mathrm{ml})$ & Number of patients & Percentage \\
\hline $\mathrm{d} " 20$ & 24 & 28.9 \\
$21-40$ & 22 & 26.5 \\
$41-60$ & 14 & 16.9 \\
$61-80$ & 10 & 12.0 \\
$81-100$ & 13 & 15.7 \\
Mean \pm SD & 44.7 & \pm 29.5 \\
Range (min-max) & 4.7 & -100.0 \\
\hline
\end{tabular}

The mean volume of prostate by USG was found $42.3 \pm 17.6 \mathrm{ml}$ ranging from 13.0 to $68.0 \mathrm{ml}$. More than one third (34.9\%) patients were found USG of prostate 41-60 ml (Table III).

Table-III: Distribution of the study patients according to USG of prostate $(n=83)$

\begin{tabular}{lcc}
\hline USG of prostate $(\mathrm{ml})$ & No. of patients & Percentage \\
\hline 20 & 16 & 19.3 \\
$21-40$ & 21 & 25.3 \\
$41-60$ & 29 & 34.9 \\
$61-80$ & 17 & 20.5 \\
Mean \pm SD & 42.3 & \pm 17.6 \\
Range (min-max) & 13.0 & -68.0 \\
\hline
\end{tabular}

The mean Gleason score was found $7.8 \pm 1.4$ ranging from 6.0 to 10.0 . 24(28.9\%) patients were found Gleason score 9 (Table IV).

Table IV: Distribution of the study patients according to Gleason score $(n=83)$

\begin{tabular}{lcc}
\hline Gleason score & Number of patients & Percentage \\
\hline $6.0(3+3)$ & 17 & 20.5 \\
$7.0(3+4)$ & 14 & 16.9 \\
$7.0(4+3)$ & 12 & 14.5 \\
$8.0(4+4)$ & 7 & 8.4 \\
$9.0(5+4)$ & 24 & 28.9 \\
$10.0(5+5)$ & 9 & 10.8 \\
Mean \pm SD & 7.8 & \pm 1.4 \\
Range (min-max) & 6.0 & -10.0 \\
\hline
\end{tabular}

The mean PSA density was found $1.30 \pm 1.29 \mathrm{ng} / \mathrm{ml} /$ $\mathrm{ml}$ ranging from 0.18 to $7.63 \mathrm{ng} / \mathrm{ml} / \mathrm{ml}$. More than one third $(33.7 \%)$ of the patients had PSA density 0.15 $0.5 \mathrm{ng} / \mathrm{ml} / \mathrm{ml}$ (Table V).

Table V : Distribution of the study patients according to PSA density $(n=83)$

\begin{tabular}{lcc}
\hline $\begin{array}{l}\text { PSA density } \\
(\mathrm{ng} / \mathrm{ml} / \mathrm{ml})\end{array}$ & Number of patients & Percentage \\
\hline $0.15-0.5$ & 28 & 33.7 \\
$0.51-1.0$ & 17 & 20.5 \\
$1.1-1.5$ & 9 & 10.8 \\
$1.51-2.0$ & 8 & 9.6 \\
$2.1-2.5$ & 8 & 9.6 \\
$2.51-3.0$ & 8 & 9.6 \\
$>3.0$ & 5 & 6.0 \\
Mean \pm SD & 1.30 & \pm 1.29 \\
Range (min-max) & 0.18 & -7.63 \\
\hline
\end{tabular}

3 patients were found Gleason score $9(5+4)$ in PSA density ranging from $0.51-1.0 \mathrm{ng} / \mathrm{ml} / \mathrm{ml}, 5$ patients in PSA density ranging from $1.1-1.5 \mathrm{ng} / \mathrm{ml} / \mathrm{ml}, 3$ patients in PSA density ranging from 1.51-2.0 ng/ $\mathrm{ml} / \mathrm{ml}, 6$ patients in PSA density ranging from $2.1-2.5 \mathrm{ng} / \mathrm{ml} /$ $\mathrm{ml}, 5$ patients in PSA density ranging from $2.51-3.0 \mathrm{ng} /$ $\mathrm{ml} / \mathrm{ml}$ and 2 patients in PSA density $>3.0 \mathrm{ng} / \mathrm{ml} / \mathrm{ml}$. The difference was statistically significant $(p<0.05)$ among seven groups (Table VI).

Scatter diagram showing positive correlation $(\mathrm{r}=0.717$; $\mathrm{p}=0.001$ ) between PSA density with Gleason score (Figure 1).

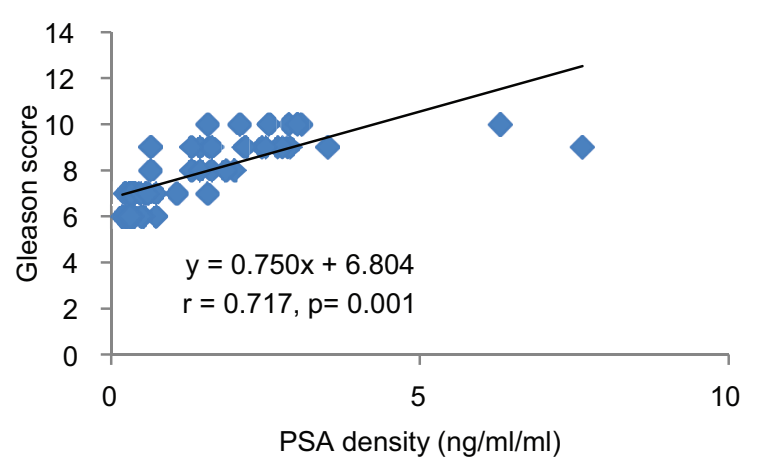

Fig.-1: Scatter diagram showing positive correlation $(r=0.717 ; p=0.001)$ between PSA density with Gleason score. 
Table 6: Association between PSA density with Gleason score ( $n=83)$

\begin{tabular}{|c|c|c|c|c|c|c|c|c|}
\hline \multicolumn{4}{|c|}{ Gleason score } & \multicolumn{4}{|l|}{ PSA density } & \multirow{2}{*}{$\begin{array}{c}\mathrm{P} \\
\text { value }\end{array}$} \\
\hline & $\begin{array}{c}0.15-0.5 \mathrm{ng} / \\
\mathrm{ml} / \mathrm{ml} \\
(\mathrm{n}=28)\end{array}$ & $\begin{array}{c}0.51-1.0 \mathrm{ng} / \\
\mathrm{ml} / \mathrm{ml} \\
(\mathrm{n}=17)\end{array}$ & $\begin{array}{c}1.1-1.5 \mathrm{ng} / \\
\mathrm{ml} / \mathrm{ml} \\
(\mathrm{n}=9)\end{array}$ & $\begin{array}{c}1.51-2.0 \mathrm{ng} / \\
\mathrm{ml} / \mathrm{ml} \\
(\mathrm{n}=8)\end{array}$ & $\begin{array}{c}2.1-2.5 \mathrm{ng} / \\
\mathrm{ml} / \mathrm{ml} \\
(\mathrm{n}=8)\end{array}$ & $\begin{array}{c}2.51-3.0 \mathrm{ng} / \\
\mathrm{ml} / \mathrm{ml} \\
(\mathrm{n}=8)\end{array}$ & $\begin{array}{c}>3.0 \mathrm{ng} / \\
\mathrm{ml} / \mathrm{ml} \\
(\mathrm{n}=5)\end{array}$ & \\
\hline $6.0(3+3)$ & 14 & 3 & 0 & 0 & 0 & 0 & 0 & \\
\hline $7.0(3+4)$ & 14 & 0 & 0 & 0 & 0 & 0 & 0 & \\
\hline $7.0(4+3)$ & 0 & 10 & 1 & 1 & 0 & 0 & 0 & \\
\hline $8.0(4+4)$ & 0 & 1 & 3 & 3 & 0 & 0 & 0 & $0.001^{\mathrm{s}}$ \\
\hline $9.0(5+4)$ & 0 & 3 & 5 & 3 & 6 & 5 & 2 & \\
\hline $10.0(5+5)$ & 0 & 0 & 0 & 1 & 2 & 3 & 3 & \\
\hline
\end{tabular}

$P$ value reached from chi square test

\section{Discussion:}

The Present study evaluating the relationship of PSA density and the gleason score which was collected from histopathology report after prostate biopsy.

There is a widespread consensus that the PSA level testing is the best available method for prostate cancer screening. Its utilization increases the detection of prostate cancer in up to $81 \%$ as compared with digital rectal examination alone. $8,9,10$

In this present study it was observed that $37(44.6 \%)$ patients belonged to age 61-70 years. The mean age was found $69.2 \pm 7.7$ years ranging from 50 to 85 years. In a study by Magheli et al. (2010) observed that the mean \pm SD patient age was $61.6 \pm 5.8$ years (median 62 , range 37 to 74$).{ }^{11}$ It is similar with the study done by Corcoran et al. (2011) in that study the median age was found 61.7 years. ${ }^{12}$

In this series it was observed that majority (28.9\%) patients had S.PSA $\leq 20 \mathrm{ng} / \mathrm{ml}$. The mean S.PSA was found $44.7 \pm 29.5 \mathrm{ng} / \mathrm{ml}$ ranging from 4.7 to $100.0 \mathrm{ng} /$ ml. In the study Magheli et al. (2010) the mean preoperative PSA was $8.32 \pm 5.28 \mathrm{ng} / \mathrm{ml}$ (median 7.30, range 0.40 to 43.20$)^{11}$.

In this current study it was observed that twenty four $(28.9 \%)$ patients were found Gleason score $9(5+4)$. The mean Gleason score was found $7.8 \pm 1.4$ ranging from 6.0 to 10.0). In Nowroozi et al. (2016) study observed that the mean Gleason score was $6.03 \pm 1.45^{13}$.

In this study it was observed that more than one third $(33.7 \%)$ of the patients had PSA density $0.15-0.5 \mathrm{ng} /$ $\mathrm{ml} / \mathrm{ml}$. The mean PSA density was found $1.30 \pm 1.29$ $\mathrm{ng} / \mathrm{ml} / \mathrm{ml}$ ranging from 0.18 to $7.63 \mathrm{ng} / \mathrm{ml} / \mathrm{ml}$.
Nowroozi et al. (2016) study showed that the mean PSA density was $0.27 \pm 0.17^{13}$. In the study Magheli et al. (2010) the mean PSA density was found $0.72 \pm 0.19$ $\mathrm{ng} / \mathrm{ml} / \mathrm{cm}^{11}$.

. In this study the mean Gleason score was $7.8 \pm 1.4$ ranging from 6.0 to 10.0. More than one third (33.7\%) patients had PSA density ranging from $0.15-0.5 \mathrm{ng} /$ $\mathrm{ml} / \mathrm{ml}$. Three patients had found Gleason score $9(5+4)$ within PSA density ranging from $0.51-1.0 \mathrm{ng} / \mathrm{ml} / \mathrm{ml}$, 5 patients within PSA density ranging from $1.1-1.5 \mathrm{ng} /$ $\mathrm{ml} / \mathrm{ml}, 3$ patients within PSA density ranging from $1.51-2.0 \mathrm{ng} / \mathrm{ml} / \mathrm{ml}, 6$ patients within PSA density ranging from $2.1-2.5 \mathrm{ng} / \mathrm{ml} / \mathrm{ml}, 5$ patients within PSA density ranging from $2.51-3.0 \mathrm{ng} / \mathrm{ml} / \mathrm{ml}$ and 2 patients PSA density $>3.0 \mathrm{ng} / \mathrm{ml} / \mathrm{ml}$ In the study Catalona et al. (1997) reported that cancer was significantly associated with more prior screening visits $(\mathrm{P}=0.03)$, lower prostate volume $(\mathrm{P}=.03)$, and higher PSA density $(\mathrm{P}=.01)^{14}$.

In this series it was observed that positive correlation $(r=0.717 ; p=0.001)$ between PSA density with Gleason score. Similar observation was found Sfoungaristos and Perimenis (2013) study they showed there was a statistically significant correlation between preoperative PSA $(p=0.005)$, PSA density $(p=0.002)$, and Gleason score $(p=0.015)$ and disease recurrence ${ }^{15}$.

\section{Conclusion}

In this study, we find there is a strong correlation between PSA density and Gleason score.

\section{References}

1. Ellsworth, P., 2011.100 Questions \& Answers About Men's Health: Keeping You Happy \& Healthy Below the Belt. Jones \& Bartlett Publishers, USA: p. 11. 
2. Oesterling, J.E., Chan, D.W., Epstein, J.I., Kimball, A.W., Bruzek, D.J. and Rock, R.C., 1988. Prostate specific antigen in the preoperative and postoperative evaluation of localized prostatic cancer treated with radical prostatectomy. J Urol. 139, pp. 766-772.

3. Silletti, J.P., Gordon, G.J., Bueno, R., Jaklitsch, M. and Loughlin, K.R., 2007. Prostate Biopsy: Past, Present, and Future. Urology, 69, pp. 413-416.

4. Benson, M.C., Whang, I.S., Pantuck, A., Ring, K., Kaplan, S.A., Olsson, C.A. and Cooner, W.H., 1992. Prostate specific antigen density: a means of distinguishing benign prostatic hypertrophy and prostate cancer. J Urol. 147, pp. 815-816.

5. Catalona, W.J., Smith, D.S. and Ornstein, D.K., 1997. Prostate Cancer Detection in Men with Serum PSA Concentrations of 2.6 to $4.0 \mathrm{ng} / \mathrm{mL}$ and Benign Prostate Examination Enhancement of Specificity with Free PSA Measurements. JAMA, 277, pp. 1452-1455.

6. McAninch, J.W. and Lue, T.F., 2013. Smith and Tanagho's General Urology. $18^{\text {th }}$ edition, McGrawHill Companies, USA; p. 362.

7. Aref, I., Eapen, L., Agboola, O. and Cross, P., 1998. Is prostate specific antigen density an important prognostic indicator for patients with prostate cancer treated with external beam therapy. The British Journal of Radiology, 71, pp. 868-871.

8. Gomes R, Rebello LEFS, Araújo FC, et al. A prevenção do câncer de próstata: uma revisão da literatura. Rev CS Col. 2008;13:235-46.

9. Nickel JC. Inflammation and benign prostatic hyperplasia. Urol Clin North Am. 2008;35:10915.

10. Catalona WJ, Richie JP, Ahmann FR, et al. Comparison of digital rectal examination and serum prostate specific antigen in the early detection of prostate cancer: results of a multicenter clinical trial of 6,630 men. J Urol. 1994;151:1283-90

11. Magheli, A., Hinz, S., Hege, C., Stephan, C., Jung, K., Miller, K. and Lein, M., 2010. Prostate Specific Antigen Density to Predict Prostate Cancer Upgrading in a Contemporary Radical Prostatectomy Series: A Single Center Experience. The Journal of Urology, 183, pp. 126-132.

12. Corcoran, N.M., Casey, R.G., Hong, M.K.H., Pedersen, J., Connolly, S., Peters, J., Harewood, L., Gleave, M.E., Costello, A.J., Hovens, C.M. and Goldenberg, S.L., 2011. The ability of prostatespecific antigen (PSA) density to predict an upgrade in Gleason score between initial prostate biopsy and prostatectomy diminishes with increasing tumour grade due to reduced PSA secretion per unit tumour volume. BJUI, pp. 1-6.

13. Nowroozi, M.R., Momeni, S.A., Moghadam, S.O., Ayati, E., Mortazavi, A., Arfae, S., Jamshidian, H., Taherimahmoudi, M. and Ayati, M., 2016. Prostate-Specific Antigen Density and Gleason Score Predict Adverse Pathologic Features in Patients with Clinically Localized Prostate Cancer. Nephrourol Mon. 8(6), pp. e39984.

14. Catalona, W.J., Smith, D.S. and Ornstein, D.K., 1997. Prostate Cancer Detection in Men with Serum PSA Concentrations of 2.6 to $4.0 \mathrm{ng} / \mathrm{mL}$ and Benign Prostate Examination Enhancement of Specificity with Free PSA Measurements. JAMA, 277, pp. 1452-1455.

15. Sfoungaristos, S., Katafigiotis, I. and Perimenis, P., 2013. The role of PSA density to predict a pathological for low risk clinical prostatecancer in the modified Gleason system era. CUAJ. 7, pp. E722-7. 